\title{
Large-scale irrigation impacts socio-cultural values: An example from rural Navarre, Spain
}

\begin{abstract}
Large-scale irrigation is a form of agricultural intensification aimed at increasing productivity and adapting to climate change. However, we know little about how large-scale irrigation affects socio-cultural values over nature's contributions to people (NCP). In this article, we fill this gap by investigating how a large-scale irrigation project in Navarre, Spain, has affected farmers' values in relation to their farming systems and the local environment. We find that large-scale farmers who participate in the irrigation project value more highly regulating NCP than small-scale farmers who have not adopted such technology, while the latter hold higher values for non-material NCP related to cultural identity and traditional knowledge and experience. These findings suggest that the adoption of large-scale irrigation technology is associated with a set of values that underestimate the long-term ecological effects of agricultural intensification and neglect the relevance of traditional farming in sustaining more ecologically and culturally diverse landscapes.
\end{abstract}

\section{INTRODUCTION}

Agricultural intensification has significantly reconfigured European rural landscapes since the 1970s (Plieninger et al. 2013, van Zanten et al. 2014). Intensification is aimed at raising agricultural and land-use productivity by investments in man-made capital (e.g. agrochemical inputs and irrigation technology), land consolidation policies, and public subsidies (Marie et al. 2009, Zarrilli 2010). While intensification has increased the production of food, fibres and livestock products (Foley et al. 2005, Tilman et al. 2011), it has also resulted in significant environmental and social impacts (van Zanten et al. 2014, Rasmussen et al. 2018). Agricultural intensification in Europe has negatively affected biodiversity (Donald et al. 2006) and ecosystem health (Casalí et al. 2008, Heathcote and Downing 2012), impairing key ecosystem services, such as climate, air quality (Erisman et al. 2008) and disease regulation (Jones et al. 2013). From a social perspective, agricultural intensification has led to the marginalization and exclusion of small-scale producers (Murgida et al. 2014, Andreas and Zhan 2016) and eroded cultural landscapes associated with traditional agricultural practices (Plieninger et al. 2013, O'Rourke et al. 2016).

The literature on the effects of agricultural intensification on ecosystem services has mainly focused on biophysical indicators, e.g. soil water holding capacity or biodiversity (Albizua et al., 2015; Brady et al., 2015; Lescourret et al., 2015) and this has led to focusing on trade-offs between ecosystem services and different constituents of wellbeing (e.g., Rassmussen et al 
This document is the Accepted Manuscript version of a Published Work that appeared in final form in:

Albizua A., Pascual U., Corbera E. 2019. Large-scale Irrigation Impacts Socio-cultural Values: An Example from Rural Navarre, Spain. ECOLOGICAL ECONOMICS. 159. 354-361. DOI

(10.1016/j.ecolecon.2018.12.017).

(C) 2019 Elsevier B.V. All rights reserved.

This manuscript version is made available under the CC-BY-NC-ND 3.0 license

http://creativecommons.org/licenses/by-nc-nd/3.0/

2018). Likewise, there is an emergent interest in valuing agrarian ecosystem services (e.g., Calvet-Mir et al. 2012, Langemeyer et al. 2015).

Here we adopt the recent IPBES approach that links the framework on nature's contributions to people (NCP) (Diaz et al., 2015; Díaz et al., 2018) with a pluralistic valuation framework (Pascual et al. 2017). The NCP framing provides a useful lens to understand farmers' sociocultural perceptions and values of NCP that are coproduced in agroecosystems, including material (e.g. food), non-material (e.g. identity, recreation and inspiration), and regulating contributions (e.g. soil formation). The IPBES approach acknowledges the role of culture as mediating the way NCP are valued by people (Pascual et al. 2017). Culture, thus, is not confined to cultural services, but pervades the way people perceive themselves in relation to nature. This implies that the values people assign to NCP are socio-culturally embedded and expressed in context-dependent ways. The NCP approach highlights instrumental as well as relational values -i.e. importance of nature in fostering desirable relationships among people through nature and between people and nature (Chan et al. 2016, Pascual et al. 2017). In addition, the contributions made by agrarian ecosystems to human wellbeing are connected to the virtues and values held by farmers about stewardship and care of agricultural land, which in turn are closely connected to farmers' sense of identity and quality of life.

There remain important knowledge gaps regarding how agricultural intensification affects farmers' socio-cultural values over NCP. For example, in agrarian ecosystems, coproduced material NCP tend to be valued in a short-term temporal scale despite farmers' land management influences associated regulating NCP, such as pollination or soil and groundwater quality over the long term. Identifying farmers' socio-cultural values over NCP can help us better understand the temporal trade-offs of prioritizing material NCP over regulating or non-material NCP. In this article, we analyse how farmers assign socio-cultural values to NCP attending to their management decisions, in a context where agricultural intensification has been promoted through a large-scale irrigation project.

We present an empirical study from Navarre (Spain) of farmers' socio-cultural valuation of NCP along a gradient of land management intensity based on quantitative and qualitative data. We investigate to which extent the introduction of large-scale modern irrigation infrastructure, as part of a large-scale intensification context, has affected farmers' values on NCP. In the next section, we introduce the case study and describe the data collection and methods. Then, we present and discuss key results in terms of a) farmers' perceptions and socio-cultural values over NCP; b) the relationship between the adoption of modern irrigation and NCP values, and c) the trade-offs across NCP values.

\section{METHODS}

\section{Study area}

The case study area is located in Navarre, Spain, along the northern banks of the Ebro River. Here, a large-scale irrigation project known as Itoiz Canal de Navarra has been developed (2006-present) to irrigate an area of 37.445 hectares via a canal of about $120 \mathrm{~km}$. The Spanish and Navarre governments have promoted and funded the project with $60 \%$ and $40 \%$ of public 
This document is the Accepted Manuscript version of a Published Work that appeared in final form in:

Albizua A., Pascual U., Corbera E. 2019. Large-scale Irrigation Impacts Socio-cultural Values: An Example

from Rural Navarre, Spain. ECOLOGICAL ECONOMICS. 159. 354-361. DOI

(10.1016/j.ecolecon.2018.12.017).

(c) 2019 Elsevier B.V. All rights reserved.

This manuscript version is made available under the CC-BY-NC-ND 3.0 license

http://creativecommons.org/licenses/by-nc-nd/3.0/

funding, respectively. Likewise, the regional government, coordinated with other Spanish administrations and European strategies, has provided farmers with public subsidies to mainstream modern irrigation as a strategy to counteract productivity losses and climate variability.

The irrigation project has affected 22 villages where 34.500 thousand people lived (in 2016). The population is rather aged, with $63 \%$ of the inhabitants being 65 years old or more. A large part of the area affected by the irrigation project was previously cultivated under traditional gravity-fed irrigation system that took water away from the river and transported it via small ancient canals (acequias). Water within each of these canals was considered common property and each farmer had use rights and was entitled to irrigation water. This traditional system had persisted for centuries until the modern irrigation system was deployed and came to replace the traditional system in most villages of the studied region.

The modern irrigation technology adopters now employ pressure sprinklers to irrigate crops such as maize and other cereals, and a drip-based system for other cash crops such as vegetables and vineyards. The irrigation project has also involved changes in the types of crops grown, being maize and forage the ones that have been predominantly introduced. Most farmers have now abandoned traditional crops associated with higher labour requirements such as asparagus, peppers and fruit trees, which now compete with imports from countries like China and Peru. Farmers are also switching to agrofuel production (de Vries and Garcia 2012). 
This document is the Accepted Manuscript version of a Published Work that appeared in final form in: Albizua A., Pascual U., Corbera E. 2019. Large-scale Irrigation Impacts Socio-cultural Values: An Example from Rural Navarre, Spain. ECOLOGICAL ECONOMICS. 159. 354-361. DOI (10.1016/j.ecolecon.2018.12.017).

(C) 2019 Elsevier B.V. All rights reserved.

This manuscript version is made available under the CC-BY-NC-ND 3.0 license http://creativecommons.org/licenses/by-nc-nd/3.0/

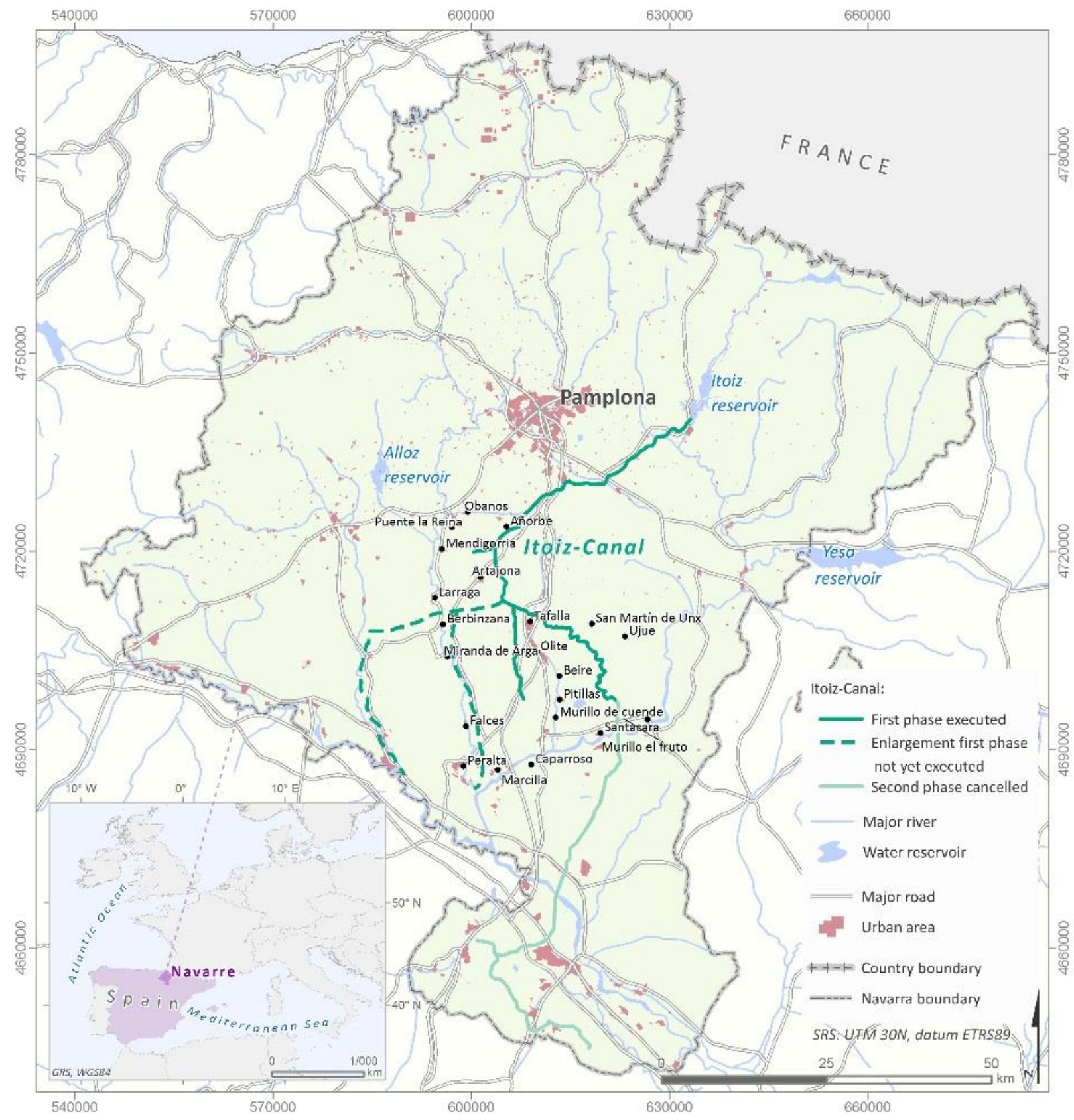

Fig 1. Location of Navarre province in Spain and Phase 1 and enlargement (2006-2017) of the Itoiz-Canal de Navarra irrigation project. All the names appearing along the canal are the villages where farmers were surveyed and interviewed

In some irrigated areas, farmers have doubled yields (mostly under a combination of maize and leguminous crops, such as peas). However, such gains in productivity have not been 
This document is the Accepted Manuscript version of a Published Work that appeared in final form in:

Albizua A., Pascual U., Corbera E. 2019. Large-scale Irrigation Impacts Socio-cultural Values: An Example from Rural Navarre, Spain. ECOLOGICAL ECONOMICS. 159. 354-361. DOI

(10.1016/j.ecolecon.2018.12.017).

(C) 2019 Elsevier B.V. All rights reserved.

This manuscript version is made available under the CC-BY-NC-ND 3.0 license

http://creativecommons.org/licenses/by-nc-nd/3.0/

realized without disputes. The irrigation project has resulted in social conflicts because access to modern irrigation was only offered to landholdings of more than 5 hectares (Horta et al. 2003). Such pre-requisite induced the concentration of small-scale properties into larger scale landholdings. Some of the farmers, not willing to invest in the new technology, left their lands in the hands of the local rural cooperative -i.e. such farmers have abandoned their rural activity and the cooperative hires other farmers to labour such lands. Other farmers either rented or sold their land to other farmers.

Access to communal farming land has also been altered with the development of the largescale irrigation project. Local councils have been increasingly prone to allocate communal land to full-time and young farmers, who are the main adopters of the modern irrigation technology. Additionally, irrigation water governance has shifted away from the community of irrigators to a private company, who is now in charge of dealing with the allocation and monitoring of water rights and consumption. The project has been at the core of the transformation of the agricultural landscape from previously mosaic-like landscape configuration to a highly homogenous landscape (Ferrandez Verdu et al. 2017).

\section{Field methods}

\section{Semi-structured interviews}

During May-July 2013, 29 in-depth interviews were carried out following a snowball selection process. The interviews were aimed at providing key informants with information about the research and to obtain first-hand information for survey design. Interviews helped identify contextual factors relevant for the interpretation of quantitative data on values. The interviewees included scientists $(\mathrm{N}=1)$, policy-makers $(\mathrm{N}=4)$, NGO representatives $(\mathrm{N}=2)$, farmer union representatives $(\mathrm{N}=2)$, cooperative workers $(\mathrm{N}=1)$, members of consumer groups $(\mathrm{N}=2)$, water management companies representative $(\mathrm{N}=1)$, an agricultural extension officer from Navarre's government $(\mathrm{N}=3)$, and local farmers $(\mathrm{N}=13)$. Interviews lasted between 30 minutes to 1.5 hours.

\section{Value-focused survey}

Between August 2013 and December 2013, 381 surveys aimed at understanding farmers' values regarding agrarian NCP were delivered to farmers living in the 22 villages affected by the Itoiz Canal de Navarra irrigation project (c.f. Figure 1). Eight surveys were found invalid due to 'missing data' and were discarded, which left us with a final sample of $\mathrm{N}=373$. Twentyfour percent of the surveyed individuals were farmers over 65 years old; $73 \%$ were between 30 and 65 years old; and only 3\% were below 30 years old. Among these, only $6 \%$ were women and their age ranged between $30-60$ years old. As regards their farming systems, $60 \%$ of the surveyed farmers grew mostly maize and other cereals in areas of 10 to 200 hectares; $34 \%$ grew vegetables and woody crops, such as olive and almond trees in small plots (0-1 hectares); and the remaining $6 \%$ cultivated cereals and vineyards under rain-fed systems operating in farms smaller than 10 hectares. 
This document is the Accepted Manuscript version of a Published Work that appeared in final form in:

Albizua A., Pascual U., Corbera E. 2019. Large-scale Irrigation Impacts Socio-cultural Values: An Example from Rural Navarre, Spain. ECOLOGICAL ECONOMICS. 159. 354-361. DOI

(10.1016/j.ecolecon.2018.12.017).

(C) 2019 Elsevier B.V. All rights reserved.

This manuscript version is made available under the CC-BY-NC-ND 3.0 license

http://creativecommons.org/licenses/by-nc-nd/3.0/

The survey's sample size was calculated based on Newing et al. (2011) to achieve a 95\% confidence level given a population frame of 2,555 farmers. The surveys were conducted by the lead author of the article, and two research assistants who were trained for such purpose. Probability sampling was followed in the selection of participants. Farmers were randomly contacted via telephone to schedule a date to complete the survey. The research team used a face-to-face approach. The survey typically lasted between one and one a half hour and, as in the case of interviews, the research project was briefly introduced, and consent was orally pursued.

The survey collected data on a variety of issues related to agricultural intensification via the introduction of the large-scale irrigation project and its impact on farmers' livelihoods (for more details see Albizua et al. (2016)). A section of the survey was designed to carry out a sociocultural valuation method based on the Pebble approach (Colfer 2005, Langemeyer et al. 2015) to capture information about the extent to which farmers valued agrarian NCP and why. The Pebble method consisted in participants distributing 15 stones among 13 image cards associated with different NCP identified a-priori based on interaction with key informants. The distribution of the pebbles by each farmer indicated the weight given to each of the NCP (see supplementary material for equivalence of NCP with ecosystem services categories and six dimensions of human wellbeing being considered).

We first calculated the mean values associated with each valuation-related question. These values were then ordered from highest to lowest and compared graphically. Dispersion measures were also contemplated to find out which NCP were perceived most differently by respondents. The data were analysed using the $R$ statistical software ( $R$ i386 3.1.2.). The quantitative results were further interpreted with the qualitative information provided by key informants.

We conducted ordination multivariate analysis to understand how multiple response variables were simultaneously related to one or more predictor variables. Principal Component Analysis (PCA) was used on the Pebble valuation data. We explored if there were significant differences in the relative NCP values among four groups of farmers using a Chi-square test and Spearman and Kruskal-Wallis tests (García-Llorente et al. 2011; Martín-López et al. 2012, Iniesta-Arandia et al. 2014). A False Discovery Rate (FDR) control approach was used to counteract the problem of multiple comparisons (Brown 2006).

Focus groups

In December 2016, two focus group discussions were performed to gain a better understanding of why and how modern irrigation might be shaping farmers' socio-cultural values over NCP. The focus groups took place in the villages of Artajona and Miranda de Arga, involving nine and eight farmers, respectively. These farmers either were from these villages or came from other locations in the northern and southern regions of the study area. By selecting these two villages, we aimed to fairly represent the villages affected by ItoizCanal de Navarra project. In both focus groups, there were farmers that represented the three different livelihoods we had identified in the case study area (see above). 
This document is the Accepted Manuscript version of a Published Work that appeared in final form in:

Albizua A., Pascual U., Corbera E. 2019. Large-scale Irrigation Impacts Socio-cultural Values: An Example from Rural Navarre, Spain. ECOLOGICAL ECONOMICS. 159. 354-361. DOI

(10.1016/j.ecolecon.2018.12.017).

(C) 2019 Elsevier B.V. All rights reserved.

This manuscript version is made available under the CC-BY-NC-ND 3.0 license

http://creativecommons.org/licenses/by-nc-nd/3.0/

We interacted with each participant in advance, to help the farmers feel comfortable during the focus groups. Additionally, we sent an email beforehand including the program and list of participants, which allowed them to consider issues and the opportunity to reflect on possible opinions (Barbour 2005). An assistant transcribed the session while the lead author facilitated the discussion. Each focus group lasted between four and five hours, and some food was offered afterwards, which allowed for a more informal conversation about values over NCP and their perceptions about the introduction and adoption of modern irrigation by themselves and among peers. The focus groups were transcribed and coded for analytical purposes. Table 1 summarizes our research methods and data sources.

Table 1 Summary of the data sources

\begin{tabular}{|c|c|c|}
\hline Data source & Demographic & Purpose \\
\hline $\begin{array}{l}\text { Qualitative } \\
\text { interviews }\end{array}$ & $\begin{array}{l}29 \text { interviews randomly selected } \\
\text { including farmers, scientists, } \\
\text { policy-makers, NGOs, cooperative } \\
\text { workers, consumer groups and } \\
\text { water management companies' } \\
\text { officers }\end{array}$ & Identification of relevant NCP \\
\hline $\begin{array}{l}\text { Quantitative } \\
\text { household } \\
\text { survey }\end{array}$ & $\begin{array}{l}373 \text { households randomly } \\
\text { selected from the } 22 \text { villages } \\
\text { affected by Itoiz-Canal de Navarra } \\
\text { project }\end{array}$ & Pebble method \\
\hline $\begin{array}{l}\text { Focus } \\
\text { groups }\end{array}$ & $\begin{array}{l}2 \text { focus groups (17 individuals in } \\
\text { total) intentionally selected: } \\
\text { farmers and landholders from } \\
\text { Artajona, Mendigorria, Miranda de } \\
\text { Arga, Peralta and Murillo el Fruto }\end{array}$ & $\begin{array}{l}\text { Analysis of farmers' perceptions } \\
\text { about the importance of assets } \\
\text { influencing their NCP valuations } \\
\text { and how such perspectives and } \\
\text { values had evolved over time }\end{array}$ \\
\hline
\end{tabular}

Source: own elaboration

\section{RESULTS}

\section{Socio-cultural values over NCP}

This section presents farmers' valuation of NCP. During the interviews, we identified all relevant NCP in the study region, and we captured our informants' diverse perceptions over such contributions. Perception is here understood as the farmers own framing for understanding and awareness about agrarian NCP (see Figure 2 and supplementary material). The Pebble valuation method permitted distinguishing farmers' values across the identified NCP, i.e. the relative importance attached to each of the perceived NCP. From all statements about NCP (image cards) we found that regulating NCP were the most commonly reported ones (up to nine NCP were reported), followed by non-material NCP (seven), and material (two). Not surprisingly, food NCP as primarily material NCP scored the highest values. This was also the one with highest standard deviation, which suggests that the surveyed valued food rather differently. Material NCP was followed by regulation NCP related to soil 
This document is the Accepted Manuscript version of a Published Work that appeared in final form in:

Albizua A., Pascual U., Corbera E. 2019. Large-scale Irrigation Impacts Socio-cultural Values: An Example from Rural Navarre, Spain. ECOLOGICAL ECONOMICS. 159. 354-361. DOI

(10.1016/j.ecolecon.2018.12.017).

(C) 2019 Elsevier B.V. All rights reserved.

This manuscript version is made available under the CC-BY-NC-ND 3.0 license

http://creativecommons.org/licenses/by-nc-nd/3.0/

fertility and water regulation. Habitat creation and soil erosion prevention NCP followed next as most important NCP. Then non-material NCP, such as education and maintenance of traditional knowledge, were also valued by farmers (Figure 2).

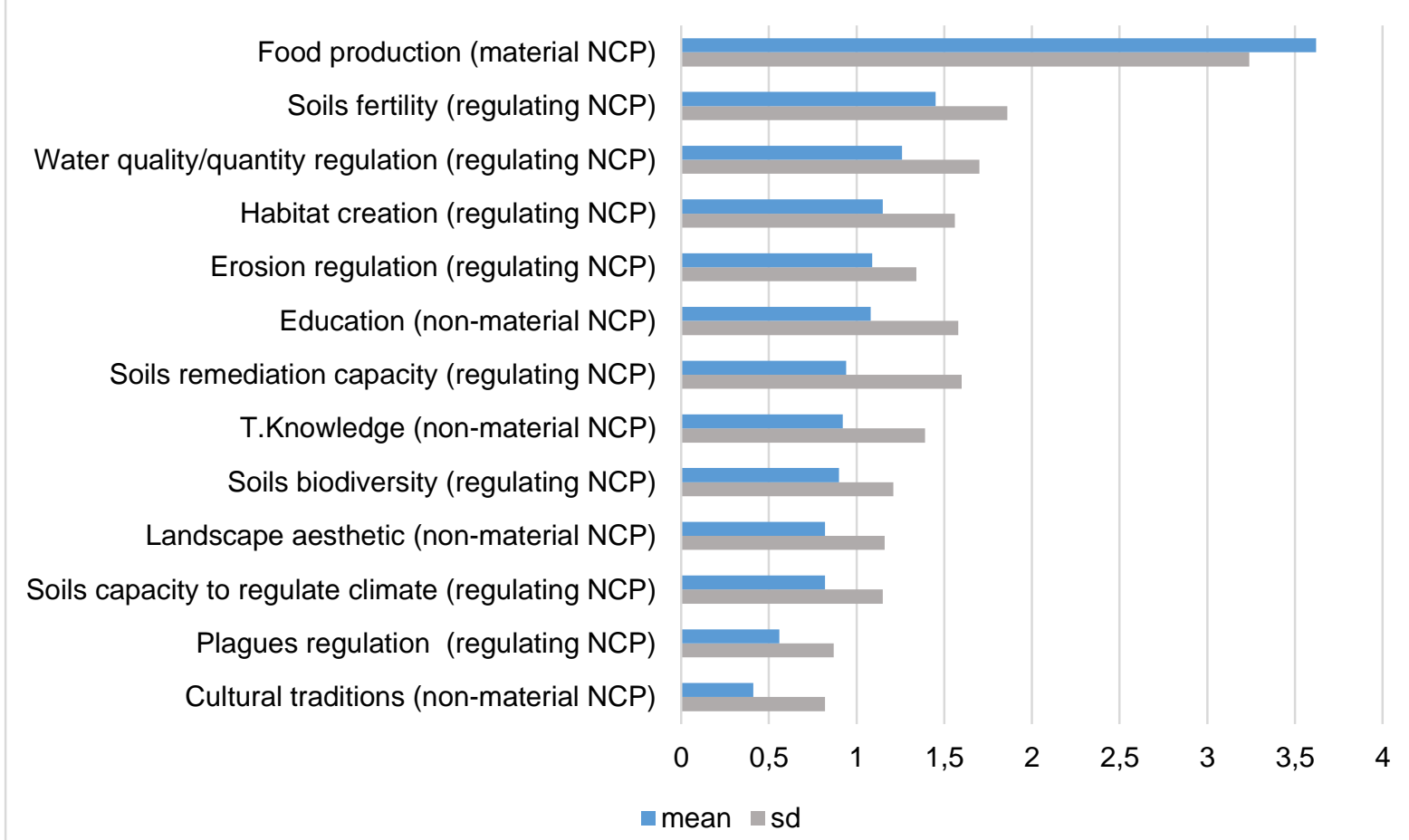

Fig 2. Mean and standard deviation of relative values attached to agrarian NCP based on the Pebble method

\section{Access to and adoption of modern irrigation influences values over agrarian NCP}

When considering features related to agrarian intensification, such as modern irrigation adoption and laboured land area, we found significant differences among farmers who engaged in more market-driven farming compared to farmers who had not got involved in the large-scale irrigation project and who laboured smaller plots. Figure 3 shows the Spearman correlation test applied to laboured land area and relative NCP values. The vertical axis represents farmers' NCP values and the horizontal axis represents the strength of association between laboured land area (mostly under irrigation) and values assigned to NCP as well as the direction of such relationship. Positive bars indicate that the larger the land area, the larger are the values assigned to NCP (illustrated in blue); negative bars indicate an inverse relationship (illustrated in red). 
This document is the Accepted Manuscript version of a Published Work that appeared in final form in:

Albizua A., Pascual U., Corbera E. 2019. Large-scale Irrigation Impacts Socio-cultural Values: An Example from Rural Navarre, Spain. ECOLOGICAL ECONOMICS. 159. 354-361. DOI

(10.1016/j.ecolecon.2018.12.017).

(C) 2019 Elsevier B.V. All rights reserved.

This manuscript version is made available under the CC-BY-NC-ND 3.0 license

http://creativecommons.org/licenses/by-nc-nd/3.0/

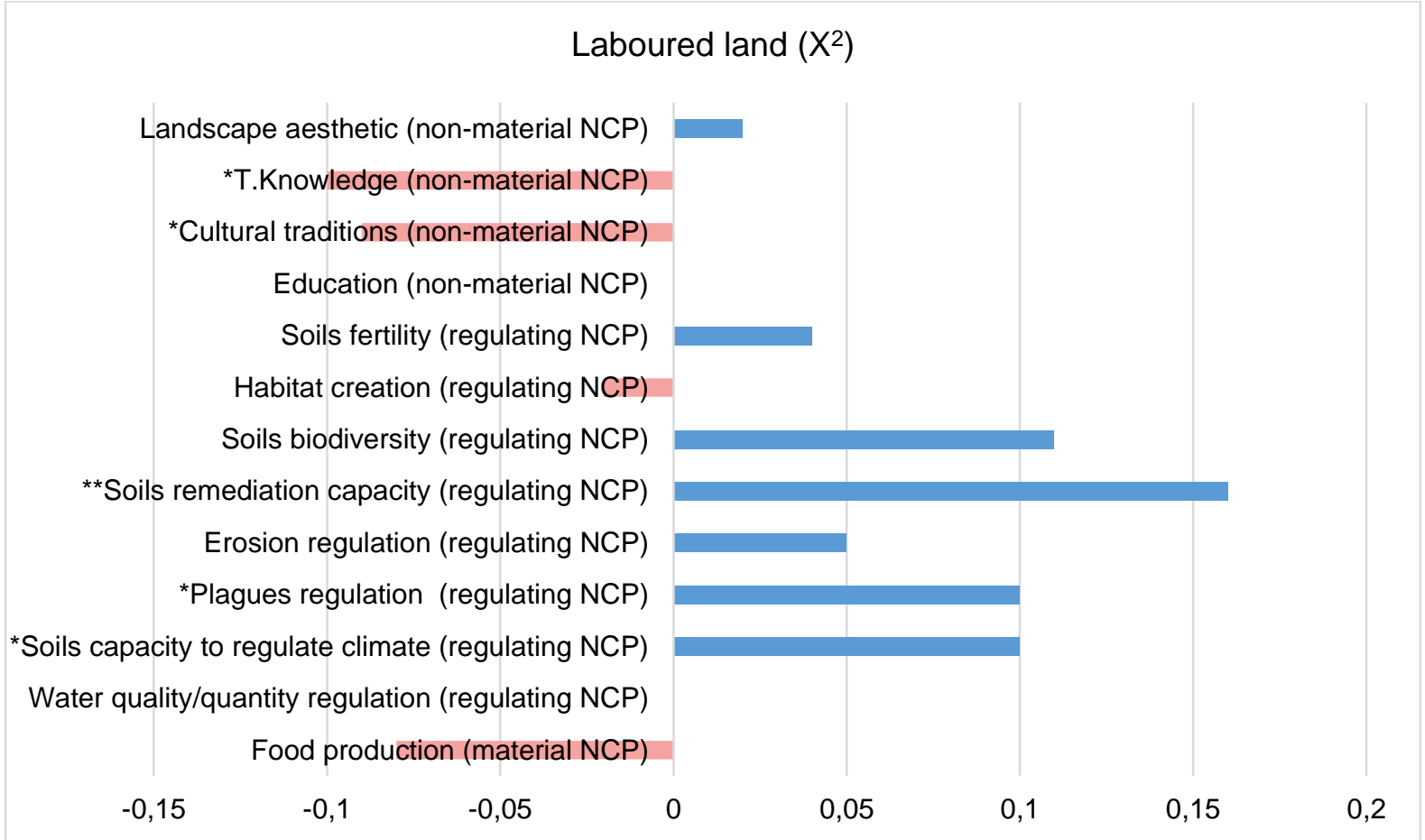

Fig 3. Differences of NCP values considering the laboured land area. Co-relation of the value attached to NCPs and the area laboured by farmers $(0.3, \min -2.51$, max $)$. Significance levels: “*' 0.05 ; ‘*” 0.01 .

Farmers labouring larger plots, normally to grow maize and other cereal crops, value more highly the capacity of their land to regulate climate and biological plagues. Interestingly, they also attach more value to the capacity of agricultural soil to absorb pollutants. By contrast, large-scale farmers assign lower values to non-material NCP, such as maintaining cultural traditions and traditional knowledge.

During the interviews and focus groups, small-scale farmers emphasised the importance of producing high quality food, whereas large-scale farmers were more concerned about the financial benefits and the jobs their farms provided. An additional reason behind this finding may be related to the fact that some of these farmers are growing crops for agrofuels and animal feed instead of crops for direct human consumption. In contrast, small-scale farmers who grow crops mostly for their own consumption ${ }^{1}$ emphasised that knowing what they were eating was essential to them. The quality of their crops and the latter's contribution to health and wellbeing was critical to them. Some of these farmers also emphasised how farming was a source of inspiration and leisure. In the words of one of them:

\footnotetext{
1 'Few', 'some', 'many' and 'most' are used consistently to mean less than 25 per cent, up to 50 per cent, up to 74 per cent and 75 per cent or more of the corresponding sample, respectively.
} 
This document is the Accepted Manuscript version of a Published Work that appeared in final form in:

Albizua A., Pascual U., Corbera E. 2019. Large-scale Irrigation Impacts Socio-cultural Values: An Example from Rural Navarre, Spain. ECOLOGICAL ECONOMICS. 159. 354-361. DOI

(10.1016/j.ecolecon.2018.12.017).

(C) 2019 Elsevier B.V. All rights reserved.

This manuscript version is made available under the CC-BY-NC-ND 3.0 license

http://creativecommons.org/licenses/by-nc-nd/3.0/

"I prefer vineyard to cereal cultivation because I find it more creative and meaningful for myself. The vines depend more on the person who manages it. You need a good soil; but obtaining different types of grapes depends on how you manage the plant. This makes you a kind of artist because you are creating it somehow. You cannot imagine after doing that work, how satisfactory is admiring the vine, since it sprouts, then grows, until it becomes old. I mime my plants. It is similar with my vegetable garden. I find it entertaining. I go there happy even when it is late in the evening. While I irrigate, I am cutting and holding tomatoes, making cucumbers go up on a net. This gives me illusion, labouring cereal now does not" (I.1.2. Full-time farmer with irrigated and rainfed crops).

Other small-scale farmers emphasized the educational values associated with small-scale farming:

'Land provides me a great opportunity for my daughters' education about natural cycles. Contemplating such cycles is like knowing yourself better. It offers continuous knowledge about what is life within yourself. It is not easy to find elsewhere something like this if you do not have access to land. (...) Nature shows that life is continuously renovated. You know you will have new seeds (new knowledge), which will make you grow and the cycle starts anew. I find this so interesting that I would never exchange it for anything else" (I.1.11. Part time female traditional small-scale farmer)

Figure 4 shows the relative NCP values of farmers who adopted modern irrigation viz-a-viz those who did not adopt it. Farmers who adopted modern irrigation rank the capacity of land to absorb pollutants $(p=0.03)$ (as large-scale farmers did) and regulate plagues $(p=0.01)$ higher than the rest of farmers. 
This document is the Accepted Manuscript version of a Published Work that appeared in final form in:

Albizua A., Pascual U., Corbera E. 2019. Large-scale Irrigation Impacts Socio-cultural Values: An Example from Rural Navarre, Spain. ECOLOGICAL ECONOMICS. 159. 354-361. DOI

(10.1016/j.ecolecon.2018.12.017).

(C) 2019 Elsevier B.V. All rights reserved.

This manuscript version is made available under the CC-BY-NC-ND 3.0 license

http://creativecommons.org/licenses/by-nc-nd/3.0/

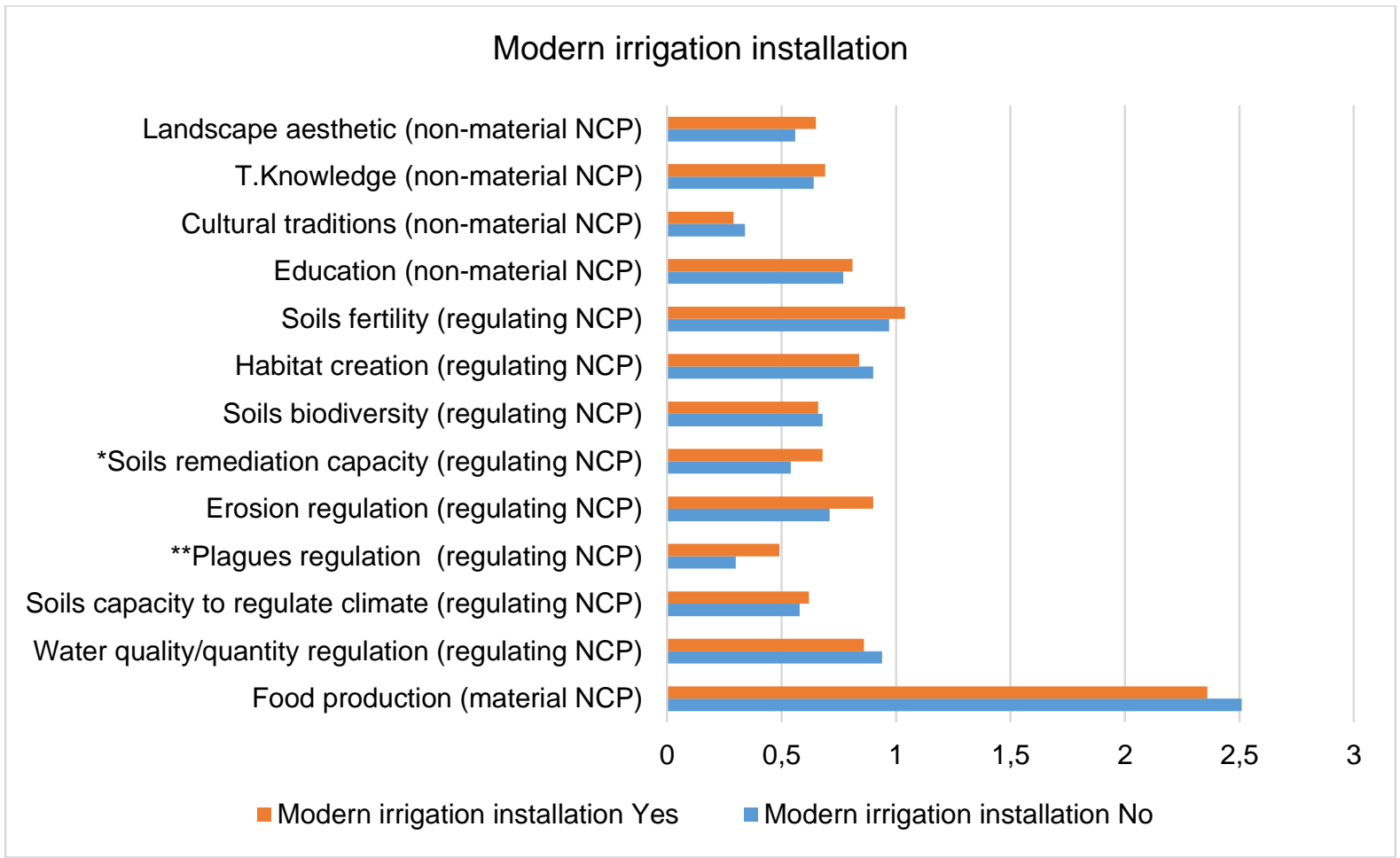

Fig 4. Valuation differences regarding adoption or not of modern irrigation technology

Co-relation of the value attached to NCPs and whether farmers adopted modern irrigation or not $\left(0, \min -2.5\right.$, max). Significance levels at $0.05\left(^{*}\right)$ and $0.01\left(^{* *}\right)$.

Focus group discussions and some interviews shed some light about why irrigators attached a higher value to regulating NCP. One of the large-scale irrigators indicated that "In the past (before modern irrigation was introduced in the region), there were fewer plagues. However, there are more now" (FG2.2 - Full-time medium scale irrigator), to what a small-scale farmer traditional irrigator added" Progress implies producing more but of less quality and increasing plagues and pollution" (FG2.3 - small scale diversified farmer). These ideas were also expressed differently by a large-scale irrigator:

"Some chemical components from fertilisers or pesticides that are prohibited in Europe but not prohibited in other countries appear in our fields probably because they are brought in the seed bags we are buying... I know someone whose crops were tested, and they found forbidden products that he had not added himself. This is incredible; but our globalised world works like that now" (I.12)

Regarding land remediation capacity, a medium-scale irrigator indicated that "Land is fulfilling an important mission because it is absorbing an important amount of waste (talking about treatment system muds) that, if not added to land, would create a problem. I do not know where else this waste could be employed" (I.2. - full time farmer). 
This document is the Accepted Manuscript version of a Published Work that appeared in final form in:

Albizua A., Pascual U., Corbera E. 2019. Large-scale Irrigation Impacts Socio-cultural Values: An Example from Rural Navarre, Spain. ECOLOGICAL ECONOMICS. 159. 354-361. DOI

(10.1016/j.ecolecon.2018.12.017).

(C) 2019 Elsevier B.V. All rights reserved.

This manuscript version is made available under the CC-BY-NC-ND 3.0 license

http://creativecommons.org/licenses/by-nc-nd/3.0/

\section{NCP values across farmer livelihood profiles}

We developed a trade-off analysis of NCP values through a principal component analysis (PCA), based on the Pebble data (see Figure 1 and Table 2 in the Appendix). Two components, including one representing the importance attributed to material NCP and another representing a mix of regulating and non-material NCP, explain $23 \%$ of the total variance. The PCA of the 13 NCP used in the Pebble exercise required up to six components to meet the Kaiser (1960) criterion (having an eigenvalue higher than one) and explained $57 \%$ of the variance regarding farmers' values about NCP.

The high values attached to material NCP are represented on the left-hand side of the horizontal axis in Figure 1 in the Appendix, while the high values associated with regulation and non-material NCP (e.g., traditional knowledge, cultural traditions, and aesthetic landscape values) appear on the right-hand side of the horizontal axis. This suggests that when regulation and non-material NCP were highly valued, the values of material NCP were relatively low. This trade-off explains about $12 \%$ of the total variance. The third component indicates a trade-off in that when land is highly valued for its habitat NCP, as source of biodiversity and as a source of food, its value as a source of regulating pollutants was relatively low.

\section{Additional qualitative analysis of socio-cultural values}

Focus group discussions were used to validate the findings from the Pebble approach and the insights provided by our interviewees. Farmers commonly agreed that agrarian intensification through modern irrigation had strongly influenced their land management choices, thus making them more conscious about the importance that regulating NCP played in the agrarian system. They concurred that modern irrigation was conducive to soil degradation, particularly given the impact of irrigation with sprinklers over clay soils, as Santos et al., (2003) confirm in their experiments. Likewise, they perceived that irrigation could drive pest infections since some areas of the plots were sometimes flooded due to the topography of the farms, which in turn favoured pest appearance (e.g. Ostrinia nubilalis and Tetranychus urticae, common in irrigated maize crops and Septoria tritici and Puccinia striiformis in winter wheat and barley crops).

For most focus group participants, modern irrigation had contributed to the concentration of land in fewer hands and the removal of traditional hedges that separated plots belonging to different farmers, which had an impact on landscape configuration and habitat and species diversity. However, they also highlighted that irrigation alone did not determine their management decisions: other factors, such as their age or access to subsidies, influenced which crops to grow and whether or not to adopt modern irrigation.

As regards the adoption of large-scale irrigation and the role of policy and values in the process, a lively debate about the interaction between values and policies highlighted two different positions held by farmers. One position is reflected by what a medium-scale intense farmer stated: "I do not think policies influence our values, but they do affect the way we 
This document is the Accepted Manuscript version of a Published Work that appeared in final form in:

Albizua A., Pascual U., Corbera E. 2019. Large-scale Irrigation Impacts Socio-cultural Values: An Example from Rural Navarre, Spain. ECOLOGICAL ECONOMICS. 159. 354-361. DOI

(10.1016/j.ecolecon.2018.12.017).

(C) 2019 Elsevier B.V. All rights reserved.

This manuscript version is made available under the CC-BY-NC-ND 3.0 license

http://creativecommons.org/licenses/by-nc-nd/3.0/

manage land". The other position was expressed by another participant arguing that "... if a given policy forces you to do something, it is indirectly influencing your values. I have no doubt that if agrarian policies benefitted organic farming all of us would change to organic farming".

In addition, farming livelihoods and values remained strongly bound for farmers. For example, a farmer who switched from conventional to organic farming stated: "My values about NCP were similar to the values I hold now. When I decided to switch it was because the way farming was being done seemed like a crime to me. I am ashamed of how little food is valued. Price is the only thing considered. Organic farmers are committed to food and biodiversity". Most farmers in the focus groups aligned their views in that modern irrigation was contributing to the disappearance of small-scale farming, and that medium-scale farming might be at risk in the longer term. They also stressed that the values over NCP associated with less intensive management systems might disappear, particularly those over non-material NCP. In the words of a medium-scale farmer of Miranda de Arga, "you must act as you think because otherwise you end up thinking in the way you act".

\section{DISCUSSION}

The Pebble valuation approach reveals that regulation NCP (necessary for long-term environmental sustainability), and non-material NCP (that is often associated with pro-social behaviour) are being eclipsed by shorter term, material NCP values. Such value trade-offs are widely acknowledged in the literature (Chan et al. 2012, Iniesta-Arandia et al. 2014). However, the trade-off is not clear-cut. When comparing across farmer groups in the study area, we find that some regulating NCP are valued more highly by larger scale farmers who tend to rely on modern irrigation technology whereas non-material NCP related to their cultural identity and traditional knowledge are more appreciated by small-scale diversified farmers.

Large-scale farmers who have adopted modern irrigation are indeed aware of the impacts that such technological adoption might have on environmental sustainability. However, since they have been involved in the project for a few years, they tend to downplay the likelihood of soil erosion or the breakout of plagues occurring in the near future. Small-scale farmers expressed stronger relational values towards land. Key among their values is their identity stemming from maintaining their cultural traditions and traditional knowledge. Such identity awareness opens a space for virtuous social responsibility towards others, and specifically about how land should be managed. Their values reflect intertwined personal and collective well-being objectives.

The discussions in the focus groups also demonstrate that policies promoting agricultural intensification strongly influence farmers' decision-making and that farmers are aware of how such policies influence their farming systems and values. This poses a challenge to the Greening Common Agricultural Policies in Europe and associated incentives, to the extent that the latter may result in the policy desired land-use in the short-term but also in unexpected losses in local knowledge and the values sustaining biodiverse landscapes (Arponen et al. 2013, Finger and El Benni 2013, Arata and Sckokai 2016). 
This document is the Accepted Manuscript version of a Published Work that appeared in final form in:

Albizua A., Pascual U., Corbera E. 2019. Large-scale Irrigation Impacts Socio-cultural Values: An Example from Rural Navarre, Spain. ECOLOGICAL ECONOMICS. 159. 354-361. DOI

(10.1016/j.ecolecon.2018.12.017).

(C) 2019 Elsevier B.V. All rights reserved.

This manuscript version is made available under the CC-BY-NC-ND 3.0 license

http://creativecommons.org/licenses/by-nc-nd/3.0/

Furthermore, insights from the focus groups suggest that small-scale farmers are losing access to water. Agricultural intensification has individualised water access and control, since now there is an external agency to allocate and monitor irrigation water whereas the traditional irrigation system, which embedded important socio-cultural values related to community mutualism, is slowly disappearing. Modern irrigation has also started to reduce collective action related to water management, which some being to see in a positive light since now they do not depend on others' when it comes to water access and use. The introduction of modern irrigation has thus negatively impacted social cohesion and incentives for collective action in water governance, which in turn affect socio-cultural values. If the number of farmers who still value non-material NCP continues to decrease, future generations might not benefit from the possibilities that such legacy could offer, such as local knowledge, traditions and customs or some educational resources. (Henle et al. 2008; van Zanten et al. 2014).

\section{CONCLUSIONS}

Understanding the diversity of worldviews, interests and values is critical for identifying the obstacles that hamper sustainable land use (Pascual et al. 2017). A pluralistic valuation framework where both instrumental and relational values are accounted for can provide key information through which individuals and communities can validate and initiate actions, addressing issues of agency and empowerment (Martinez-Harms et al. 2018). This paper has focused on the values and related trade-offs held by farmers affected by a modern irrigation project in Navarre, Spain.

By employing a socio-cultural valuation approach that relies in quantitative and qualitative data, the article has shed light on the effects that the adoption of large-scale modern irrigation technology has (and might have in the future) on farmers' values over the contributions that agrarian ecosystems offer to people. We have found that a) by contrast to small scale farmers, who hold strong relational values to land, more intensive farmers adopting modern irrigation place low values on non-material NCP, b) collective action and social cohesion is rapidly eroding as a result of modern irrigation and related processes (e.g. land concentration), and c) large scale farmers perceive regulating NCP as key, especially with regard to soil fertility and regulation of plagues, and mostly from an individualistic and instrumental perspective to fulfil their relative short term financial objectives.

Valuing NCP requires considering the diversity of worldviews, interests and plurality of values (including both instrumental and relational). This also requires acknowledging multiple constituents of wellbeing going beyond material aspects (Díaz et al. 2015, 2018; Pascual et al, 2017; Rassmusen et al 2018). As we have shown, in what apparently seems to be a homogenous region, the introduction of a given technology to advance agricultural intensification is resulting in profound and potentially long-lasting effects on livelihoods and also on the values farmers hold. The impact of intensification is not only physically observable in terms of land use change. The values underpinning the social-ecological system are also affected. Any policy aiming at sustainable land use thus needs to consider the co-evolution of values, livelihoods, technologies and incentives in rapidly changing landscapes. 
This document is the Accepted Manuscript version of a Published Work that appeared in final form in:

Albizua A., Pascual U., Corbera E. 2019. Large-scale Irrigation Impacts Socio-cultural Values: An Example from Rural Navarre, Spain. ECOLOGICAL ECONOMICS. 159. 354-361. DOI

(10.1016/j.ecolecon.2018.12.017).

(C) 2019 Elsevier B.V. All rights reserved.

This manuscript version is made available under the CC-BY-NC-ND 3.0 license

http://creativecommons.org/licenses/by-nc-nd/3.0/

\section{References}

Albizua, A., U. Pascual, and E. Corbera. 2016, October. Social-ecological impacts of agrarian intensification: The case of modern irrigation in Navarre.

Albizua, A., A. Williams, K. Hedlund, and U. Pascual. 2015. Crop rotations including ley and manure can promote ecosystem services in conventional farming systems.

Andreas, J., and S. Zhan. 2016. Hukou and land: market reform and rural displacement in China. Journal of Peasant Studies 43(4):798-827.

Arata, L., and P. Sckokai. 2016. The impact of agri-environmental schemes on farm performance in five EU member states: a DID-matching approach. Land Economics 92(1):167-186.

Arponen, A., R. K. Heikkinen, R. Paloniemi, J. Pöyry, J. Similä, and M. Kuussaari. 2013. Improving conservation planning for semi-natural grasslands: Integrating connectivity into agri-environment schemes. Biological Conservation 160:234-241.

Barbour, R. S. 2005. Making sense of focus groups. Medical education 39(7):742-750.

Brady, M. V., K. Hedlund, R.-G. Cong, L. Hemerik, S. Hotes, S. Machado, L. Mattsson, E. Schulz, and I. K. Thomsen. 2015. Valuing Supporting Soil Ecosystem Services in Agriculture: A Natural Capital Approach. Agronomy Journal 107(5):1809-1821.

Brown, S. R. 2006. A match made in heaven: A marginalized methodology for studying the marginalized. Quality and Quantity 40(3):361-382.

Calvet-Mir, L., E. Gómez-Baggethun, and V. Reyes-García. 2012. Beyond food production: Ecosystem services provided by home gardens. A case study in Vall Fosca, Catalan Pyrenees, Northeastern Spain. Ecological Economics 74:153-160.

Cardinale, B. J., J. E. Duffy, A. Gonzalez, D. U. Hooper, C. Perrings, P. Venail, A. Narwani, G. M. Mace, D. Tilman, and D. A. Wardle. 2012. Biodiversity loss and its impact on humanity. Nature 486(7401):59.

Casalí, J., R. Gastesi, J. Álvarez-Mozos, L. M. De Santisteban, J. Lersundi, R. Giménez, A. Larrañaga, M. Goñi, U. Agirre, M. A. Campo, and others. 2008. Runoff, erosion, and water quality of agricultural watersheds in central Navarre (Spain). agricultural water management 95(10):1111-1128.

Chan, K. M. A., P. Balvanera, K. Benessaiah, M. Chapman, S. Díaz, E. Gómez-Baggethun, R. Gould, N. Hannahs, K. Jax, S. Klain, G. W. Luck, B. Martín-López, B. Muraca, B. Norton, K. Ott, U. Pascual, T. Satterfield, M. Tadaki, J. Taggart, and N. Turner. 2016. Opinion: Why protect nature? Rethinking values and the environment. Proceedings of the National Academy of Sciences 113(6):1462-1465.

Chan, K. M., A. D. Guerry, P. Balvanera, S. Klain, T. Satterfield, X. Basurto, A. Bostrom, R. Chuenpagdee, R. Gould, and B. S. Halpern. 2012. Where are cultural and social in ecosystem services? A framework for constructive engagement. BioScience 62(8):744-756.

Colfer, C. J. P. 2005. The Equitable Forest: Diversity, Community and Resource Management. Resources for the Future. Center for International Forestry Research(CIFOR), Washington, DC.

De Groot, R. S., M. A. Wilson, and R. M. Boumans. 2002. A typology for the classification, description and valuation of ecosystem functions, goods and services. Ecological economics 41(3):393-408. 
This document is the Accepted Manuscript version of a Published Work that appeared in final form in:

Albizua A., Pascual U., Corbera E. 2019. Large-scale Irrigation Impacts Socio-cultural Values: An Example from Rural Navarre, Spain. ECOLOGICAL ECONOMICS. 159. 354-361. DOI

(10.1016/j.ecolecon.2018.12.017).

(C) 2019 Elsevier B.V. All rights reserved.

This manuscript version is made available under the CC-BY-NC-ND 3.0 license

http://creativecommons.org/licenses/by-nc-nd/3.0/

Díaz, S., S. Demissew, J. Carabias, C. Joly, M. Lonsdale, N. Ash, A. Larigauderie, J. R. Adhikari, S. Arico, A. Báldi, and others. 2015. The IPBES Conceptual Frameworkconnecting nature and people. Current Opinion in Environmental Sustainability 14:116.

Díaz, S., U. Pascual, M. Stenseke, B. Martín-López, R. T. Watson, Z. Molnár, R. Hill, K. M.

A. Chan, I. A. Baste, K. A. Brauman, S. Polasky, A. Church, M. Lonsdale, A. Larigauderie, P. W. Leadley, A. P. E. van Oudenhoven, F. van der Plaat, M. Schröter, S. Lavorel, Y. Aumeeruddy-Thomas, E. Bukvareva, K. Davies, S. Demissew, G. Erpul, P. Failler, C. A. Guerra, C. L. Hewitt, H. Keune, S. Lindley, and Y. Shirayama. 2018. Assessing nature's contributions to people. Science 359(6373):270-272.

Donald, P. F., F. J. Sanderson, I. J. Burfield, and F. P. J. van Bommel. 2006. Further evidence of continent-wide impacts of agricultural intensification on European farmland birds, 1990-2000. Agriculture, Ecosystems \& Environment 116(3):189-196.

Erisman, J. W., A. Bleeker, A. Hensen, and A. Vermeulen. 2008. Agricultural air quality in Europe and the future perspectives. Atmospheric Environment 42(14):3209-3217.

Ferrandez Verdu, T., J. A. Pujol Fructuoso, and F. Almarcha Martinez. 2017. Historical evolution of Medieval fauna in the Lower Segura, Alicante (Spain). Anthropozoologica 52(2):203-214.

Finger, R., and N. El Benni. 2013. Farmers' adoption of extensive wheat productionDeterminants and implications. Land Use Policy 30(1):206-213.

Foley, J. A., R. DeFries, G. P. Asner, C. Barford, G. Bonan, S. R. Carpenter, F. S. Chapin, M. T. Coe, G. C. Daily, and H. K. Gibbs. 2005. Global consequences of land use. Science 309(5734):570-574.

García-Llorente, M., B. Martín-López, S. Díaz, and C. Montes. 2011. Can ecosystem properties be fully translated into service values? An economic valuation of aquatic plant services. Ecological Applications 21(8):3083-3103.

Heathcote, A. J., and J. A. Downing. 2012. Impacts of eutrophication on carbon burial in freshwater lakes in an intensively agricultural landscape. Ecosystems 15(1):60-70.

Henle, K., D. Alard, J. Clitherow, P. Cobb, L. Firbank, T. Kull, D. McCracken, R. F. Moritz, J. Niemelä, and M. Rebane. 2008. Identifying and managing the conflicts between agriculture and biodiversity conservation in Europe-A review. Agriculture, Ecosystems \& Environment 124(1):60-71.

Horta, M. Á., A. Arranz, and J. Olona. 2003. Gestión del agua, economía y territorio en Navarra: una valoración de los efectos socioeconómicos del Canal de Navarra. Quinto Congreso de Economía de Navarra.

Iniesta-Arandia, I., M. García-Llorente, P. A. Aguilera, C. Montes, and B. Martín-López. 2014. Socio-cultural valuation of ecosystem services: uncovering the links between values, drivers of change, and human well-being. Ecological Economics 108:36-48.

Inman, A., M. Winter, R. Wheeler, E. Vain, A. Lovett, A. Collins, I. Jones, P. Johnes, and W. Cleasby. 2018. An exploration of individual, social and material factors influencing water pollution mitigation behaviours within the farming community. Land Use Policy 70:16-26.

Jones, B. A., D. Grace, R. Kock, S. Alonso, J. Rushton, M. Y. Said, D. McKeever, F. Mutua, J. Young, J. McDermott, and D. U. Pfeiffer. 2013. Zoonosis emergence linked to 
This document is the Accepted Manuscript version of a Published Work that appeared in final form in:

Albizua A., Pascual U., Corbera E. 2019. Large-scale Irrigation Impacts Socio-cultural Values: An Example from Rural Navarre, Spain. ECOLOGICAL ECONOMICS. 159. 354-361. DOI

(10.1016/j.ecolecon.2018.12.017).

(C) 2019 Elsevier B.V. All rights reserved.

This manuscript version is made available under the CC-BY-NC-ND 3.0 license

http://creativecommons.org/licenses/by-nc-nd/3.0/

agricultural intensification and environmental change. Proceedings of the National Academy of Sciences 110(21):8399-8404.

Langemeyer, J., F. Baró, P. Roebeling, and E. Gómez-Baggethun. 2015. Contrasting values of cultural ecosystem services in urban areas: The case of park Montjuïc in

Barcelona. Ecosystem Services 12:178-186.

Lescourret, F., D. Magda, G. Richard, A.-F. Adam-Blondon, M. Bardy, J. Baudry, I. Doussan, B. Dumont, F. Lefevre, I. Litrico, R. Martin-Clouaire, B. Montuelle, S. Pellerin, M. Plantegenest, E. Tancoigne, A. Thomas, H. Guyomard, and J.-F. Soussana. 2015. A social-ecological approach to managing multiple agro-ecosystem services. Current Opinion in Environmental Sustainability 14:68-75.

Marie, M., A. Bensaid, and D. Delahaye. 2009. Impact of distance on agricultural practices and landscapes organization: case study of dairy farm functioning in Western Europe. Cybergeo-European Journal of Geography:UNSP 460.

Martinez-Harms, M. J., S. Gelcich, R. M. Krug, F. J. Maseyk, H. Moersberger, A. Rastogi, G. Wambugu, C. B. Krug, E. M. Spehn, and U. Pascual. 2018. Framing natural assets for advancing sustainability research: translating different perspectives into actions. Sustainability Science:1-13.

Martín-López, B., I. Iniesta-Arandia, M. García-Llorente, I. Palomo, I. Casado-Arzuaga, D. G. D. Amo, E. Gómez-Baggethun, E. Oteros-Rozas, I. Palacios-Agundez, B. Willaarts, J. A. González, F. Santos-Martín, M. Onaindia, C. López-Santiago, and C. Montes. 2012. Uncovering Ecosystem Service Bundles through Social Preferences. PLoS ONE 7(6):e38970.

Matzdorf, B., and J. Lorenz. 2010. How cost-effective are result-oriented agri-environmental measures?-An empirical analysis in Germany. Land use policy 27(2):535-544.

MEA. 2005. Ecosystems and human well-being. Island Press Washington, DC.

Murgida, A. M., M. H. Gonzalez, and H. Tiessen. 2014. Rainfall trends, land use change and adaptation in the Chaco salteo region of Argentina. Regional Environmental Change 14(4):1387-1394.

Newing, H., C. M. Eagle, R. K. Puri, and C. W. Watson. 2011. Conducting research in conservation: social science methods and practice. Routledge.

O'Rourke, E., M. Charbonneau, and Y. Poinsot. 2016. High nature value mountain farming systems in Europe: Case studies from the Atlantic Pyrenees, France and the Kerry Uplands, Ireland. Journal of Rural Studies 46:47-59.

Pascual, U., P. Balvanera, S. Díaz, G. Pataki, E. Roth, M. Stenseke, R. T. Watson, E. Başak Dessane, M. Islar, E. Kelemen, V. Maris, M. Quaas, S. M. Subramanian, H. Wittmer, A. Adlan, S. Ahn, Y. S. Al-Hafedh, E. Amankwah, S. T. Asah, P. Berry, A. Bilgin, S. J. Breslow, C. Bullock, D. Cáceres, H. Daly-Hassen, E. Figueroa, C. D. Golden, E. Gómez-Baggethun, D. González-Jiménez, J. Houdet, H. Keune, R. Kumar, K. Ma, P. H. May, A. Mead, P. O'Farrell, R. Pandit, W. Pengue, R. Pichis-Madruga, F. Popa, S. Preston, D. Pacheco-Balanza, H. Saarikoski, B. B. Strassburg, M. van den Belt, M. Verma, F. Wickson, and N. Yagi. 2017. Valuing nature's contributions to people: the IPBES approach. Current Opinion in Environmental Sustainability 26-27:7-16.

Plieninger, T., C. Bieling, B. Ohnesorge, H. Schaich, C. Schleyer, and F. Wolff. 2013. Exploring Futures of Ecosystem Services in Cultural Landscapes through 
This document is the Accepted Manuscript version of a Published Work that appeared in final form in:

Albizua A., Pascual U., Corbera E. 2019. Large-scale Irrigation Impacts Socio-cultural Values: An Example from Rural Navarre, Spain. ECOLOGICAL ECONOMICS. 159. 354-361. DOI

(10.1016/j.ecolecon.2018.12.017).

(C) 2019 Elsevier B.V. All rights reserved.

This manuscript version is made available under the CC-BY-NC-ND 3.0 license

http://creativecommons.org/licenses/by-nc-nd/3.0/

Participatory Scenario Development in the Swabian Alb, Germany. Ecology and Society 18(3).

Potts, S. G., J. C. Biesmeijer, C. Kremen, P. Neumann, O. Schweiger, and W. E. Kunin. 2010. Global pollinator declines: trends, impacts and drivers. Trends in Ecology \& Evolution 25(6):345-353.

Rasmussen, L., B. Coolsaet, A. Martin, O. Mertz, U. Pascual, E. Corbera, N. Dawson, J. Fisher, P. Franks, and C. Ryan. 2018. Social-ecological outcomes of agricultural intensification.

Santos, F. L., J. L. Reis, O. C. Martins, N. L. Castanheira, and R. P. Serralheiro. 2003. Comparative assessment of infiltration, runoff and erosion of sprinkler irrigated soils. Biosystems Engineering 86(3):355-364.

Tilman, D., C. Balzer, J. Hill, and B. L. Befort. 2011. Global food demand and the sustainable intensification of agriculture. Proceedings of the National Academy of Sciences 108(50):20260-20264.

Vedel, S. E., J. B. Jacobsen, and B. J. Thorsen. 2015. Forest owners' willingness to accept contracts for ecosystem service provision is sensitive to additionality. Ecological Economics 113:15-24.

Villanueva, A. J., K. Glenk, and M. Rodríguez-Entrena. 2017. Protest Responses and Willingness to Accept: Ecosystem Services Providers' Preferences towards Incentive-Based Schemes. Journal of Agricultural Economics 68(3):801-821.

Villanueva, A. J., J. A. Gómez-Limón, M. Arriaza, and M. Rodríguez-Entrena. 2015. Assessment of greening and collective participation in the context of agrienvironmental schemes: The case of Andalusian irrigated olive groves. Spanish Journal of Agricultural Research 13(4):0108.

de Vries, A., and M. Garcia. 2012. OTN Observaciones Teritoriales de Navarra. Pages 1-20. Gobierno de Navarra. Agricultura, Pamplona.

van Zanten, B. T., P. H. Verburg, M. Espinosa, S. Gomez-y-Paloma, G. Galimberti, J. Kantelhardt, M. Kapfer, M. Lefebvre, R. Manrique, A. Piorr, M. Raggi, L. Schaller, S. Targetti, I. Zasada, and D. Viaggi. 2014. European agricultural landscapes, common agricultural policy and ecosystem services: a review. Agronomy for Sustainable Development 34(2):309-325.

Zarrilli, A. 2010. An unsustainable agriculturization? The province of Chaco, Argentina (1980-2008). Historia Agraria(51):143-+. 